\title{
COURTING LEVIATHAN: \\ LIMITED GOVERNMENT AND SOCIAL FREEDOM IN REFERENCE RE SAME-SEX MARRIAGE
}

\begin{abstract}
F.C. DfCostE*
We garb Leviathan with legality nol only to legitimise his powers. but to restrain licem. and to protect each of us at our most vulucrable.

- J.R. Lucas'

[1] f despotism were to be established among the democratic nations of our days, ... it would be more extensive and mild: it would degrade men without tormenting them... [1]n an age of instruction and equality like our own. sovereigns might more casily succeed in collecting all political power into their own hands and might interfere more habitually and decidedly witl the circle of privale interests than any soveteign of antiquity could crer do... [T] he supreme power then exiends its arm over the whole community... Such a power does not destroy, but it prevents exislence. it does not tyramize. but it compresses. enervales. extinguishes. and stupelies a people, till each nation is reduced to nolhing beller thin a tlock of timid and industrious animals.
\end{abstract} of which the government is the shepherd.

- Alexis de Tocqueville 2

\section{INTRODLICTION}

In the Same-Sex Reference ' case, the Supreme Court of Canada had before it the following four questions:

1. Is the annexed Proposal for an Act respecsing ceriain aspects of legal capacin for marriage for civl purposes within the exclusive legislative authority of the Parliament of Canada? II not, in what particular or particulars, and to what extent?

2. If the answer 10 question I is yes. is section I of the proposal. which extends capacity in marry to persons of the same sex. consistent with the Canadian Charter of Kights and Freedoms? If not. in what panticular or particulars, and to what extent?

3. Does the freedom of religion guaranteed by paragraph 2(a) of the Cancadiun Churter of Rights and Freedoms protect religious oflicials from being compelled to perform a marriage between two persons of the same sex that is contrary to their religious beliefs?

Professor, Faculty of Law. University of Alberta, Edmonton. Altherta J.R. Lucas. Responsibiling (Oxford: Clarendon Press. 1993) at 118

Alexis de Tocqueville. Democracy in America. vol. 2 (New York: Vintage Classics. 1990) at 317. 319

Reference re Same-Sex. Ifarriage. [2004] 3 S.C. R. 698 [Same-Sex Reference]

Part 1 of the Constiturion Act. 1982. being Schedule B to the Canada Act 1982 (U.K.). 1982. c II [Charter]. 
4. Is the opposite sex requirement for marriage for civil purposes, as established by the common law and set out for Quebec in section 5 of the Federal Lan'-Civil Lani Harmonization Act. No. I, consistent with the Canadian Charter of Rights and Freedoms? If not. in what particular or particulars and to what extent?"

The proposed legislation — which then Justice Minister Martin Cauchon released on 17 July 2003 - reads as follows:

WHE:REAS marriage is a fundamental institulion in Canadian society and the Parliament of Canada has a responsibility to support that institution because it strengthens commitment in relationships and represents the foundation of family life for many Canadians;

WIJERLAS, in order to reflect the values of tolerance, respeet and equalily consistent with the Canadian Charter of Rights and Freedoms, access to marriage for civil purposes should be extended to couples of the same sex;

AND WHEREAS everyone has the freedom of conscience and religion under the Canadian Charter of Rights and freedoms and officials of religious groups are free to retuse to perform marriages that are not in accordance with their religious belicts:

NOW, TIERLFORE, Her Majesty, by and with the advice and consent of the Senate and House ol Commons of Canada, enacts as follows:

I. Marriage, for civil purposes, is the lawful union of two persons to the exclusion of all others.

2. Nothing in this Act affects the freedom of officials of religious groups to refuse to perform marriages that are not in accordance with their religious beliefs. ${ }^{\circ}$

This proposal was drafted, the questions framed and the entire bundle forwarded to the Court, as the federal executive's response, in lieu of appeal, to the Ontario Court of Appeal's ukase in Halpern v. Canada (A.G.), ' which directed that thereafter and immediately marriage at law must be "reformulate[d] ... as 'the voluntary union for life of two persons to the exclusion of all others.""9

Same-Sex Reference, supra note 3 at paras. 3, 4, citing Order in Council, P.C. 2003-1055 (16 July 2003) and Amendment to Order in Council 2003-1055. P.C. 2004-0028 (26 January 2004) (both made under the Supreme Court Act. R.S.C. 1985, c. S-26), online: Orders in Council <www.pcobep.ge.ca/oic-dde>. The amendment, which added the fourth question, was at the initiative of the minority Martin government. The first three questions are those of the former Chretien government.

" Department of Justice Canada. Press Release, "Reference to the Supreme Court of Canada" (17 July 2003), online: Deparıment of Justice Canada :http:/canada.justice.gc.ca/en/news/nr/2003/ doc_30946.html>.

(2003), 65 O.R. (3d) 161 [Halpern].

In this, the Ontario Court of Appeal distinguished itself from the British Columbia Court of Appeal in EGALE Canada v. Canada (A.G.) (2003). 225 D.L.R. (4th) 472 [EGALE] and from the Quebec Superior Court in Hendricks v. Québec (P.G.). [2002] R.J.Q. 2506, both of which courts - though cach reached the same result, and by the same means, as did the Ontario Court, regarding what constitutes a constitutionally proper definition of marriage - provided Parliament with a period of grace in which to enact proper legislation. Following Halpern, a three-member panel of the B.C. Court of Appeal set aside the grace period. in order to allow same-sex couples to marry immediately. As well. during the period following Halpern and before the release of the Supreme Court's opinion in the SameSex Reference, courts in Saskatchewan. Maniloba. Nova Scolia, Yukon and Newfoundland and Labrador joined the Courts in Halpern and EGALE in declaring discriminatory, under s. IS(1) of the Charfer, the opposite-sex definition of marriage and in putting in its place the Halpern definition.

Halpern, supra note 7 at para. 148. For a summary of, and comment on, the Ontario Court's reasoning to this result, see, F.C. DeCoste, "The Halpern'Transformation: Same-Sex Marriage, Civil Society, and The Limits of Liberal Law" (2003) 41 Alta. L. Rev. 619 ["Transformation"]. 
The Supreme Court heard arguments ${ }^{10}$ on the four reference questions on 6-8 October 2004, and delivered its en banc opinion," which follows, on 9 December 2004:

With respect to Question 1, we conclude that s. I of the Proposed Act is within the exclusive jurisdiction legislative competence of Parliament, while s. 2 is not.

With respect to Question 2, we conclude that $s$. I of the Proposed Act. which defines marriage as the union of two persons, is consistent with the Camadian Charter of Rights and fireetoms

With respect to Question 3, we conclude that the guaranlee of freedom of religion in the Charter aflords religious officials protection against being compelled by the stale to perform marriages between two persons of the same sex contrary to their religious heliefs.

For reasons to be explained, the Court declines to answer Question 4. 12

Though I shall comment briefly on the significance of the latter in the third part of this comment, my primary concern is the first three, excepting only the Court's opinion as regards s. 2 of the proposed legislation, which opinion appears to me to be plainly and completely correct. ${ }^{3}$ More specifically, it will be my purpose, first, to construct and, then, to condemn, the reasoning from which arises the Court's disastrous advice on the remainder of the proposed legislation.

\section{Proposal, and Premises}

The pith and substance of the Same-Sex Reference resides, of course, in the Court's advice on the constitutional propriety - if not, indeed, the constitutional necessity - of same-sex marriage (Question 2). That advice it puts in a fashion at once succinct and grand (and, one should note, with a veritable flourish of certainty and conviction): ${ }^{14}$ " $[t]$ he purpose of $s .1$ of the Proposed Act is to extend the right to civil marriage to same-sex couples," and that is "a purpose which, far from violating the Charter, flows from it." ${ }^{\text {s }}$ The remainder of the opinion consists of argumentative premises that together, and alone, allow the Court to articulate this

These arguments were tendered by counsel (all counled, 31 of them) representing both the Altorney General of Canada and a host of interveners (19 in all, several of which were multi-party). "Opinion" in a very precise sense, since reference cases are productive of advice and not of judgments that bind, alter or otherwise affect the law: Same-Sex Reference, supra note 3 at paras. 4-7.

12 On this, the Court reasoned as follows: because "[s]ection 2 of the Proposed Act relates to those who may (or must) perform martiages," because that matter "necessarily relates to the 'solemnization of marriage," because authority over that "matter is ... allocated to the provinces under s. 92(12) of the Constitution ACt. 1867," s. 2 of the proposed legislation "does not fall within the exclusive legislative competences of Parliament" under its s. 92(26) authority with respect to "Marriage and Divorce." See Same-Sex Reference, ibid. at paras. 36-39 [emphasis in original]: and Comstitution Act. 1867 (U.K). 30 \& 31 Vict., c. 3. reprinted in R.S.C. 1985 . App. II, No. 5 Same-Sex Reference, ibid. at para. 43 [emphasis added]

Turning to the substance of the provision itself. we note that $\mathbf{s}$. I embodies the government's policy stance in relation to the s. 15(1) equality concerns of same-sex couples. This, combined with the circumstances giving rise to the Proposed $\mathrm{J}$ ct and the preamble thereto, points unequivocally to a purpose which, far from violating the Charter, llows liom it. 
view of the constitutional status and significance of same-sex marriage. Those premises are: (a) that there is a distinction that counts, in law and in life as well, between what the Court terms civil marriage and religious marriage; (b) that the authority to define civil marriage resides exclusively with the state through Parliament; (c) that the state through Parliament may define civil marriage in any fashion it wishes, since marriage of that state sort has no fixed constitutional or legal meaning; and (d) that premises ' $b$ ' and ' $c$ ' are proper, because each is a requirement of a proper understanding of the place and function of the constitution in the Canadian polity. I shall dwell at some length on each, before then proceeding, in the third part of this comment, to the difference all of this makes to the delicate matters, faith and family, that are here the stuff of the Court's charge.

\section{A. The Distinction Between "Civil" and "Religious" Marriage}

Though the Court hinges the whole of its enterprise on the distinction between civil and religious marriage - straightaway we are told to note that "s. I of the Proposed ACt deals only with civil marriage, not religious marriage"16 - it avoids both definition and defense. ${ }^{17}$ In consequence, neither the sense or senses in which the Court thinks civil and religious marriage different, nor its view of the origins of the difference, is anywhere on display. Indeed, the best that the Court can muster in either regard is armchair sociology and tautology, to wit: that times have changed from those when "marriage and religion were thought to be inseparable"; 18 that "[m]arriage, from the perspective of the state, ${ }^{19}$ is a civil institution", ${ }^{20}$ and that "civil marriage" is (presumably in consequence) "a legal institution." The distinction, then, must be taken simply as an assertion, a claim, that civil and religious marriage are free-standing institutions, ${ }^{22}$ which is to say that they each exist (the former in the political sphere and the latter in social life) and that they are both separate one from the other and unrelated the one to the other. ${ }^{23}$

Ibid. at para. 1 .

As of course did the executive, initially in its framing of the reference and subsequently in its written submission. Regarding the latter, see "l'actum of the Attorncy General of Canada" (24 Octoher 2003) at paras. 1-2, 11-16, online: Department of Justice Canada <www.justice.ge.ca/en/dept/pub/actuny/ index.html>.

Same-Sex Reference, supra nute 3 at para. 22.

That it speaks in this way knowing fill well that when Parliament hats twice spoken on the matter, it did so to affirm heterosexual marriage. senders its speech both disingenuous and a remarkable departure from the separation of powers. These affirmations were each, of cuurse, in response to judicial initiative on same-sex marriage. The first was by way of a Commons motion, which was passed on 8 June 1999 by a vote of 2161055 in favour, and read as follows: "[M]arriage is and should remain the union of one man and one woman to the exclusion of all others, and ... Parliament will take all necessary steps to preserve this definition of marriage in Canada." See House of Commons Journals, No. 240 (8 June 1999) at 2064. For the second, which was no mere motion. see infra note 87. Same-Sex Reference, supra note 3 at para. 22. This formulation will be considered in Part Ill of this comment.

See e.g. ibid. at para. 16. ("The dominant characteristic of's. 1 of the Proposed Acr is apparent from its plain text: marriage as a civil institution... [T]]his section stipulates the threshold requirements of that institution.")

$\therefore \quad$ As put by the Court: "The Proposed Act is limited in its elfect to marriage for civil purposes: sec $\mathrm{s}$. I. It cannot be interpreted as affecting religious inarriage or its solemnization" (ibid. at para. 55). Yat. there may be some uncertainty here: "The right to same-sex marriage conferred by the Proposed Act may conflict with the right to freedom of religion if the Act becomes law" (ibid. at para. 52). 
This bald assertion is the critical first step towards the Court's constitutional destination. Firstly, so to assert is to establish, by mere fiat, the required state jurisdiction over - indeed, its ownership of - some form of marriage. Secondly, mere and simple statement of the distinction handily elides matters that might otherwise have complicated the jurisdictional claim. Chief among these is the question of the relationship that ought properly to obtain between the (liberal) state and the institution and practices of marriage. ${ }^{24}$ Clearly, had the Court framed that question, other, wider questions concerning the relationship of the state to social life generally and to religious and family life specifically, would have appeared. And had they appeared, the Court, I should think, would have been led to compose an opinion very different, in tone if not in substance, from the opinion it finally rendered. ${ }^{25}$ Rather than mature normative analysis of this sort, the Court appears instead content to play on, and then to cede legal and constitutional authority to, the common sense that there is a difference between marriage at city hall and marriage at a church (or synagogue, temple or mosque). Common sense, however, makes for poor political philosophy and practice, and, in any event, it ought not, ever, to serve as a basis for judicial opinion on the proper reaches of state power. Or, so at least I shall argue when I again take up the distinction in Part III of this comment.

\section{B. State Authority OVER "CiVIL." MARRIAGE:}

After birthing "civil" marriage by these meager means, the Court next delivers "civil" marriage to the care of the state. Its reasoning to this consignment is simple enough: (a) s. 1 of the Proposed Act "pertains to the capacity for marriage":;6 (b) "s. 91(26) [of the Constitution Act, 1867] confers on Parliament legislative competence in respect of the capacity to marry"; ${ }^{27}$ (c) consequently, "s. I of the Proposed Act ... falls within a subject matter allocated exclusively to Parliament." ${ }^{28}$ Yes, simple, it is; but as do all such syllogistic flourishes in law, this one too hides and shelters an absence that makes mockery of the certainty being tendered.

Over the past several years, the Supreme Court of Canada has made much of purposive, contextual reasoning, especially so as regards the interpretation of constitutional provisions. Proper interpretation of a constitutional provision, the Court has declared, begins with an

is Incidentally, that first the executive and then the Court monikers the marriage over which the state has authority, "civil" lends a note of irony to matters, since in our tradition the adjective "civil" - as in civil rights - is generally meant to impart that the matter so described exists prior to, and independent from. the state. See e.g. Lloyd L. Weinrib. "What Are Civil Rights?" (1991) 8:2 Social Philosophy \& Policy 1 at 2 (arguing as follows: "[C]ivil rights are ... prior and independent from law. Laws are enacted to protect civil rights: failing enactment, the law is said to deny them. They seem. therefore. not to depend on the law for existence. but only for recognition"). For the notion of the civil more widely: considered as civil socicly. sce imfra Part III. A

: The tone of the Court's text is at once summary and dismissive. Sec for e.g. Sume-Sex Reference. supra note 3 at paras. 24 ("none of these arguments persuade"): 25 ("the appeal to history therefore in this particular matter is not conclusive"): 30 ("it is therefore distinguishable and does not apply here"): 33 ("this is clearly not the case"), 48 ("(t)his argument was discussed above ... and was rejected"). This tone is not incidental hubris: it is instead a necessary consequence. and expression, of the Court's conviction about the moral stature and place of the constitution. About which see infra Part IJ.D and "Transformation," supra note 9 at 641.

: Same-Sex Reference, ibid. at para. 16.

27 Ibid. at para. 18. Constitution Act. 1867, supra note 13

ix Same-Sex Reference, ibid. at para. 19. 
examination of "the meaning of its words, considered in context and with a view to the purpose they were intended to serve. ${ }^{199} \mathrm{Had}$ this imperative been honoured here, ${ }^{30}$ the Court would have sought to establish the purpose served by the relevant provisions of the Constitution $A C t, 1867,{ }^{31}$ which is to say, the purpose served by the split authority over marriage erected by s. 91(26), which confers authority over "Marriage and Divorce"to Parliament, and s. 92(12), which confers on the povinces authority over "solemnization of Marriage in the Province."In so doing, the Court would have been driven to examine the legal history of the state's involvement in marriage, not just here in Canada, ${ }^{32}$ but more importantly in Britain, whose constitution the Constitution Act, 1867 declares its model. It would have then confronted the legal and social facts that would be the very stuff of purposive interpretation, namely, that because the date of the state's first involvement in marriage is available, and because marriage as a social practice and institution of course existed prior to that date, and therefore independently from the state, the state's purposes, including the purpose authorized by s. 91(26), might concern matters other than exercising power over marriage and subjecting it to its will. ${ }^{33}$

That the Court offers slick syllogism in the place of serious inquiry does, however, pay dividends, since it makes both easy and intelligible its next mission, the sounding of the depths of the state's authority over "civil" marriage.

\section{The State's Authority Over "Civil" Marriage is Limitless}

Several interveners confronted the Court with the following argument: that Parliament's authority over civil marriage under $\mathrm{s.91}$ (26) excludes the authority to define marriage in any fashion it wishes, either because the word "marriage" as used in s. 91(26) has a fixed meaning 3 or because a same-sex definition "would trench upon subject matters clearly allocated to the provincial legislatures" under s. 92(12). ${ }^{33}$ It is not important for present purposes to dwell on the arguments proffered by the interveners in support of these submissions, and not only because they are so woefully unimaginative. ${ }^{36}$ Nor, need we dwell,

R. v. Blais, [2003] 2 S.C.R. 236 at para. 16.

"1' Incidentally, the Court distinguislies Blais in a manner both curt and specious: see Same-Sex Reference. supra note 3 at para. 30.

"Constitution ACt, 1867, supra note 13

"2 In its Factum, the federal executive put before the Court a not very helpful, and very brief, legal history of the state and marriage in British North America (see supra note 17, paras. 12, 25-27, 29). A better history would direct the Court to proceed in its interpretation from the facts of social and especially religious life in Canada at that time. Viewed from that vantage, the split constitutional authority over marriage would appear designed to recognize and preserve the differing social practices of marriage and in that way to prevent either order of government from favouring one at the expense of the other. That interpretation, of course, would preclude rendering the provisions, as the Court does here, so as to vest ownership of marriage in the statc.

" For more on the social and legal history of marriagc, sec infra noles 80-87 and accompanying text.

4. Same-Sex Reference, supra note 3 at paras. 20-21. Fully stated the argument was that "the meaning of marriage is constitutionally fixed, necessarily incorporating an opposilc-sex requirement." because s $91(26)$ "effectively entrenches the common law definition of "marriage" as it stood in 1867."

" For full statement and Court's rejection of this submission, see ibid. at paras. 31-33.

3. Unimaginative: the first because intentionalist interpretation remains so in disfavour and so casily set aside (but see L.M. Solan, "Privale Language, Public Laws: The Central Role of Legislative intent in Statutory interpretation" (2004) Brooklyn Law School, Public Law Research Paper No. 5. online: Social Science Research Group <hitp://ssrn.com/abstract= 515022>): and the second because it both misses 
on the Court's response to them. Rather, what is important so far as the overall structure of the opinion is concerned is the Court's conclusion, namely, that " $[\mathrm{t}] \mathrm{he}[\mathrm{m}] \mathrm{eaning}$ of [m]arriage [i]s [n]ot [c]onstitutionally [f]ixed." 37

This must be taken to mean that, subject to judicial oversight ${ }^{38}$ (and one wonders upon what, having granted the legislative branch such a plenary authority, the judicial gaze could then fix), ${ }^{39}$ the state through Parljament may make of marriage anything it wishes. Now, this goes well beyond parliamentary supremacy in the Diceyan sense. ${ }^{40}$ What the Court is here endorsing, rather, is a positivism writ so large that the sovereign's power is bled of any normative content or constraint and so permitted, as matter of constitutional principle, to pursue whatever instrumentalism, however coarse, it wishes, for any reason it may wish.

\section{Constitution as Encomium}

The Court secures its view of state authority over civil marriage (and subsequently its view of the constitutional propriety of same-sex marriage) through a political epistemology that, though it has established itself as the idee recue among constitutional lawyers and judges in Canada, is most peculiar indeed. Under this view of matters, the Canadian Constitution the whole of it: the Constitution $\mathrm{ACl}, 1867^{41}$ every bit as much as the Charter ${ }^{42}$ - has a purpose deeper and wider than, and different from, the limitation of state power over individuals and social life. In Canada, rather, the Constitution aims at "structuring the exercise of power by the organs of the state"43 in order, first, to secure "the continued relevance and ... legitimacy" of the state's "constituting document"44 and, then, to "promot[e] [constitutional] rights and values" so as to "enric[h] ... our society as a whole."45 To achieve these ends, judicial interpretation of constitutional provisions must be "large and liberal, or progressive," ${ }^{46}$ by which is meant, at least, that provisjons must be rendered so as to "accommodat[e] and addre[ss] [the judicial branch's view of] the realities of modern life."47

the real point and makes the point it does address so badly.

Same-Sex Reference, supra note 3 at para. 21 (sub-heading).

As put hy the Court: "In essence, there is no topic that cannot be legislated upon, though the particulars of such legislation may be limited by, for instance, the Charter" (ibid. at para. 34).

1" Though having nothing upon which to fix judicial action has deterred none of the courts whose machinations have led to the present. Take, for instance, the Court in Halpern. supra note 7: it credentialized its directive concerning the law of marriage by latching onto the House of L.ords judgment in Hyde v. Hyde and Woodmansee (1866), 1 L.R. P. \& D. 130 [Hyde], which through cynicism or stupidity (and on the necessarily implied premise that betore 1866, neither the state nor the law had any conception of what marriage might be), it read as constituting marriage at law as the union of one man and one woman to the exclusion of all others. For commentary on this aspect of Halpern. see "Transformation," supra note 9 at 622-25.

" A.V. Dicey, Introduction to the Siudy of the Law of the Constitution, 8 th ed. (L.ondon: Macmillian \& Co., 1924) at c. I.

"Supra note 12. For the Court's declaration that heads of power are subject to "progressive interpretation." see Same-Sex Reference, supra note 3 at paras. 22, 29.

Supra note 4.

Same-Sex Reference, supra note 3 at para. 23.

lbid.

Ibid. at para. 46.

Ibid. at para. 23.

Jbid. at para. 22. 
This view, which, borrowing from Lord Sankey's speech in Edwards v. Canada (A.G.). ${ }^{48}$ devotees term the "'living tree' principle," 49 informs an "ambitious enterprise" $\$ 0$ that serves to expand state power and aims to bond those subject to its rule to its values in the place of their own. That this turns liberal political and legal philosophy and practice upside down and sideways should be obvious, but the reasons bear reiteration.

There are two. So far as the law generally is concerned, to think that its proper purpose is somehow about moving forward - about making better and more perfect and whole and complete the life-world - is to commit, in equal and fateful measure, to political perfectionism ${ }^{51}$ and to unlimited government. ${ }^{52}$ Both of those precepts, of course, violate commitments constitutive of the liberal state, the commitment, on the one hand, to leave alone those subject to its rule provided only they cause no harm, and the commitment, on the other hand, that follows ineluctably from this, namely, the commitment to limited and moderate government. I shall pursue these matters at greater length in the next section of this comment. It is the second reason, which concerns the place and status of a constitution in the liberal state, that is of more immediate concern.

In addition to (and even as part of) securing limited government, the constitution of a liberal state may, as does the American Constitution, ${ }^{33}$ serve as a myth of origin in the sense that it tells people about where their political arrangements came from and how the situation in which they live came about. What a liberal constitution may not do is create a caesura that separates a people from its past or that proposes a future for them that betrays limited government. Under the custodianship of Canada's judicial branch — and, increasingly, with the connivance of an ideologically committed federal executive ${ }^{54}$ and a weakened Parliament (and always, I should add, with endless applause from the legal academy) - the Constitution

15 [1930] A.C. 124 (P.C.)

4.) Same-Sex Reference, supra note 3 at para. 24.

\$1) lbid. at para. 23.

" For recent work concerning. see Steven Wall \& George Klosko, eds., Perfectionism and Neutraliny" Essays in Liberal Theon' (Lanliam, Md.: Rowman \& Littlefield, 2003); and George Sher, Beyond Neutrality: Perfectionism and Politics (New York: Cambridge University Press, 1997).

s: See e.g. Arthur A. Shenfield, Limised Governmem. Individual Liberty and the Rule of Lan (Chettenham, U.K.: Edward Elgar, 1998); and Eugene W. Hickok et al., eds., Our Peculiar Security: The Written Constitution and Limiled Governmen (Lanham, Md.: Rowman \& Littlefield. 1993). See e.g. Bruce A. Ackerman, We The People: Foundations, vol. 1 (Cambridge, Mass.: The Belknap Press of Harvard University Press, 1991).

Minister of Justice Cotler has, since his elevation to the federal executive, quickly established himself the poster boy of this ideological fervour. Recently, he intoned as follows: "The Charter is the expression and entrenchment of our rights and freedoms, the codification of the best of Canadian values and aspirations. It defines us as to who we are as a people and what we aspire to be" (Cristin Scmitz. "Tories vow to amend new bill" National Post (2 February 2005) A8). Even were this view not preposterous as political philosophy - and in a moment I shall attempt to convince that it is - it would remain silly, both because the provisions of Charter are no more than a local iteration of standard constitutional protections and because Canadian political and social history did not begin in 1982 . Concerning the latter, in a news release attending the tabling of Bill C-38 (about which sec infra, Postscripl), the Minister persists, with pride, in this historical revisionism: "Canada," he is quoted as declaring. "is a land built on a tradition of tolerance and respect, rooted in a Charter." (Department of Justice Canada, Press Release, "Government of Canada to Introduce Legislation to Extend Civil Marriage to Same-Sex Couples" (I February 2005), online: Government of Canada <http://canada.justice.gc.ca/en/news/nr/2005/doc_31374.html>). 
of Canada has, since the advent of the Charler in 1982, been interpreted so as to commit both these cardinal sins.

Authoritarian states are revolutionary states of a specific sort. They defend and articulate their legitimacy in terms of their overthrowing of forms of life, political and private, which. according to their revolutionary calculus and consciousness, have in the past subjugated the "people." Revolution of this variety makes good its promise of a new and renewed life of (generally social) justice by erasing the ancien régime and cleansing the people of any remaining affection for it. As their legitimacy resides only and always in this, authoritarian states are activist states, bent perpetually to the task of weeding the garden of lific of the past.

Because they seek legitimacy in the consent of the governed, liberal states, even those born of revolution, take a very different attitude to the past. For a start, they take seriously the real past of the people and do not, in consequence, seek its erasure, even when, under exceptional circumstances, they may for good reason judge parts of that past wanting." Nor, therefore, do they seek to reconstruct the received past in service to any dream that conjures up a life-world begun anew from scratch. Liberal states, rather, honour the people's past by seeking their consent in terms that acknowledge and proceed from that past. For just this reason, in liberal states, the law is viewed as belonging to the people: it embodies their whole way of life, and it originates not in the will of the sovereign, in any of its three guises, but in the traditions and practices of the people whose law it is.

States resign their liberal credentials when they succumb to the temptation to reject the people's past in service to delivering them to a better, because cleansed, future. Witl rare exception, ${ }^{36}$ the vast constitutional jurisprudence excreted by the judicial brancli since 1982 . has revealed a Canadian state quick to reject the past in just sucl a service. This is very much on display in the opinion here at issue. When it is argued that the people's past has proper normative and legal bite on the present, the Court declares that past now unacceptable ${ }^{57}$ and opines that the present must be managed, and the future defined, in terms of its view of the present circumstances of the people. ${ }^{58}$ When it is submitted that "marriage is a pre-legal

"4 There is a caveat here. a narrow but nonetheless essential one: if a social institulıon stands so egregiously at odds with liberal political morality that its continuance clearly compromises the liberal credentials of the state and so its status as a liberal state - such as was the case with slavery in antebellum America - then a liberal state has an obligation, just because it is a liberal state, to take un the task of abolishing the institution. For an exploration of the proper response of the liberal state to "bad civil sociely" of a less threatening sort - there detined as civil assuciations that "actively and publicly challenge [the value of reciprocity] through the promotion of hatred. bigotry, racism, anliSemilism, and aggressive xenophobia" (infra at 839-40) - see, Simone Chambers \& Jetl'rey Kopsteill. "Bad Civil Society" (2001) 29 Political Theory 837

*. As regards the instant malter, ] think of LaForest J.'s comments in Egan v. Canada. [1995] 2 S.C.R. 5।3. In a remarkably short period, LaForest J.'s concession of marriage to the realities of social life and human biology has been everywhere erased from judicial and governmental memory.

That the Coun, in an oflhanded manner, pinned the past's unacceptability on its association with Christianity will be addressed in Part Illol this comment. As pul by the Court, aller what alppears to be a reileration of the silliness in Halpern (stpra notes 9. 39). with respect to the siguilicance of the decision in Hyde: "The reference to 'Christendom' is telling. Hyde spoke to a suciety of shared social values where marriage and religion were thought to be inseparable. This is no longer the cast. ('annda is a pluralistic society" (Same-Sex Reference, supra nole 3 al para. 22). 
institution and thus cannot be fundamentally modified by law," musters poor old Lord Sanke ${ }^{60}$ to construct, irony entirely absent and certainty fairly oozing, this reason for rejecting in its entirety the people's past: "Several centuries ago it would have been understood that marriage should be available only to opposite-sex couples. The recognition of same-sex marriage in several Canadian jurisdictions as well as two European countries belies the assertion that the same is true today." When, finally, it is submitted that marriage has a natural meaning - which is to say, the meaning conferred upon it by the traditions and practices of the past - the Court declares that it falls to the "proponents" of this view to "identify an objective core meaning";, 22 that different proponents proffered "competing opinions on what the natural limits of marriage may be":63 and that, because Lord Sankey - yes, His Lordship yet again - "did not impose an obligation to determine, in the abstract and absolutely, the core meaning of constitutional terms ... it is not for the Court to determine, in the abstract, what the natural limits of marriage must be." ${ }^{.64}$ So, with and for reasons such as these, does this Court trivialize, reject and erase the people's past. With them as well, it abandons, not only those who would cleave to this past, but also its core and abiding obligation "to preserve the community of law, to discover and articulate the conditions under which political fraternity is possible." ${ }^{\text {"ts }}$ No such fraternity is possible, of course, where the discovery articulated is that the views of some - that, in this case, they appear to be the many is no matter ${ }^{66}$ - are so beyond the constitutional pale that they represent a now dead, because unacceptable, history.

The subtext of this abandonment of the past, the grammar that lends it whatever cogency it may have, is the Court's view of the positive contribution of the Constitution. However, the sketch that I have so far offered of this understanding ${ }^{67}$ is not enough, since the devil of unlimited government very much resides in the details to which we must now briefly attend.

The "living tree" notion of the place and status of the Constitution is saved from demagoguery just and only because the values that it aims to articulate, legitimize, promote and spread, all remember for the continuing enrichment of society, are stare values. Thus, does the Canadian Constitution become an encomium to the state, and the judicial branch its

(1) Ibid. at para. 24

(4) Sipra note 47.

i. Same-Sex Reference, supra note 3 at para. 25.

$\therefore \quad$ Ibid. at para. 27.

(.) Tbid.

it Ibid. at para. 28.

is Anthony Kronman, "Living in the Law" in David Luban, ed., The Ethics of Lawyers (New York: New York University Press, 1994) 835 at 870 . If Habermas is correct, then this view of judicial obligation has deep roots indeed: sec Jurgen Habermas, Moral Consciousncss and Communicative Action, Irans. by Christian Lendhardt ef al. (Cambridge, Mass.: MIT Press, 1990) it 68 ("'the justification ol norns and commands requires that a real discuurse be carried cul"). 103 ("only those norms may claim to be valid that could meet with the consent of all afrected") and - especinlly apposite here - I09 (rejecting judgments that are "dissociated from the local conventions and historical coloration ol' a particular form of life").

4. According to a poll published by the Nationai Post, 66 percent of Canadians support what the pollsters termed "the traditional definition of martiage" (Tom Blackwell, "Most want Referendum" National Post (2 February 2005) Al). 
solipsistic choirmaster. Thus too does the state, through its Constitution, commit itself to a redemptive politics that, by means and medium both, makes jest of limited government.

Redemptive politics is a politics of conviction. The redemptive state is a state convinced that its proper purpose is to improve its subjects by imprinting on them, on their projects and character, the values that the state has made its own and declared superior. Such a state is not merely a custodian and guardian of the people's proper values, though it is clearly both. The redemptive state, rather, conceives of itself as the personification of those values and, with that, of the lives of the governed properly lived. Which is to say, state and people are, in theory, one, and so do they in fact become to the extent that the state succeeds in disarming the people of values that contradict or diminish its values. But this transformation, of the state into a person and persons into expressions of the state, comes at the cost, in equal measure, of moral arrogance by the state and of the moral disablement of the people. "[T] make [of the state] a unity and a person and then to attribute to it moral existence and moral rights" requires an arrogant analogical leap - that the state has this existence and those rights because it is like a person - that cheapens and distorts real existence, not least because it "creates a world" in which politics is no longer, in the fashion required by liberal political morality, "discontinuous with everyday life."

This morally laden and motivated Leviathan has as its means, everywhere it is constructed, a reconceived citizenship and, in liberal democratic states such as ours, it is always legitimated through the soothing medium of human rights. Consistent with its view of the constitution as an encomium to its values, the redemptive state considers citizenship, not as a burdensome cost of liberty, but as a celebration of, and, in its proper conduct, as a commitment to, those values. Citizens are for it the means of its moral mission. and their commitment is the test of its moral accomplishment.

That those values are often, as in Canada now, conflated with human rights and human dignity, makes declining the state's offer of neo-citizenship a tricky and sticky affair. Though those human rights, and the dignity they are said to protect, are never conclusively defined nor ever finally disclosed, ${ }^{69}$ by declaring its values to be expressive of them, the neo-liberal state, ours especially included, repositions itself in fundamentally important ways with respect to its subjects. Whereas under the liberal view, a constitution has as its proper object the constraint of executive and legislative power, takes as its object the validity of legal rules. and has as its focus the relationship between the state and its subjects as citizens (and not as persons), the neo-constitution of human rights and dignity produces a very different normative typography. If the constitution is about human rights, then the concern of constitutional discourse and decision is the settlement of state norms concerning those rights and, with that, the consolidation of state power with respect to them; its focus is the

1.* George Kateb. The Immer Ocean: Individualism and Democratic Culmere (Ithaca: Cornell University Press, 1992) at 207, 211.

(1" Disclosure of both the unintelligibility and the ideology of human dignity and rights, happily. has recently begun. To sample the former, see Timothy Caultield, "Human ('loning I.aws. Human I)ignity. and the Poverty of the Policy Making Dialogue" (2003) 4:3 BMC Med. lithics I: and for the latler, see James Q. Whitman, “On Nazi 'Honour' and the New European 'Dignity"” in Christian Joerges \& Navraj Singh Ghaleigh, eds., Darker Legacies of Lan in Europe: The Shadow of National Socialism and Fascism Over Europe and /ts Legal Traditions (Oxford: Hart. 2003) 243. 
relationship, as regards those norms, between the state and its subjects, not as citizens, but as human persons; and the entire enterprise is finally informed, not by the constrain of state power, but by those very state norms, the settlement of which is the constitution's mission. ${ }^{70}$

In this morally engorged and socially imperialist state, law becomes the bride and pride of power and ceases to be "the bridle of power" that, since Bracton, our tradition has named it to be. "No longer does it shield the people from the state; the abnormal" law of the neoliberal, redemptive state, rather, renders them, through its insistent demands on them as persons, expressions of the state's power.

These four premises, along with the concepts and conceptions on which they depend, are, then, the powder that ignites the Court's constitutional mission and compels it to its constitutional destination. At first blush, that destination might appear a curious one. As mentioned earlier, the Court opines that same-sex marriage is not merely consistent with the Charter, but that it "flows from it." the constitution of a liberal state is properly conceived as a foundry of values to which the state is bound and not merely as a bulwark by which it is bound. In the liberal view, of course, the constitution plays no such positive purpose: it is no more and no less than an institutional strategy to limit state power. Under the Court's view, the Constitution serves the very different purpose of instructing the state on how properly to exercise its power. Viewed from that vantage, the Court's opinion must, I think. be read as declaring that same-sex marriage is a constitutional necessity.

Yet, given these premises, this should not surprise. If the state is indeed the personification of communal values and if it is therefore pledged to seed those values amongst its subjects, then it makes abundant sense to articulate, in ever finer detail, which values it must personify and promote. That this is at loggerheads with representative government and majoritarian rule appears to be of no moment to this Court or to any of the many other devotees of Canada's recently minted constitutional tradition. ${ }^{74}$

\section{The Proper Place of the Political}

As noted previously, the Court at one point opines that "marriage, from the perspective of the state, is a civil institution." This assertion conceals two premises: namely, that it is proper for the state to take a view on social institutions like marriage, and that the view taken

in

I have explored these matters in more detail elsewhere see F.C. DeCoste, "Law Transcendent: The Judicial Conquest of Ordinary Life" (2004) 8:1 The Newman Rambler I.

"I refer to. and the quoted phrase is Iaken from. Henri de Bracton. De Legibus El Consuetudinibus Angliac (1220-1230), which is available redacted and in Iranslation in Danicl R. Coquiletle, The AngloAmerican Legal Heritage (Durham. N.C.: Carolina Acidemic Press, 1999) 88 al 92.

": I mean "abnormal" in the Kuhnian sense of paradigm shifting: see Thomas $\mathbf{S}$. Kulun. The Siructure of Scientific Revolutions, 2d ed. (Clicago: University of (licago Press. 1970) at esp. c. 8.

Same-Sex Reference, supra nole 3 at para 43.

14 I have explored the implications of the value-positive view of the constitution al some length in F.C. DeCoste, "The Separation of Powers in Liberal Polity: I'riend v. Alberra" (1999) 44 McGill L.J. 231 Same-Sex Reference, supra note 3 at para. 22 [emphasis added]. 
by it here is the proper one. The real and revolutionary importance of the Court's opinion in the Same-Sex Reference resides, in my view, in its answer to the executive's views on these matters. I shall proceed as follows: first, I shall take the first premise to concern the relationship that ought properly to obtain between the liberal state and the institutions and traditions of private life and examine the executive's and the Court's views as responses to that concern; second, I shall examine the Court's views of how that relationship works out with respect to those two fundaments of private life, family and faith. In all of this, it will be my purpose to convince, so far as space will permit, that, by establishing the primacy of the political over the social, the same-sex marriage initiative has set the Canadian state on a path that threatens social freedom generally and the freedoms of family and religious life particularly.

\section{A. State and CiviL Society ${ }^{76}$}

Liberal politics expresses, and proceeds from, two core commitments, namely: that the state exists for the sake of persons, for their good and not its own (the priority of persons); and that, since the good of persons resides in their authoring their own lives through their freely chosen interactions with other persons, social life is prior, and superior, to politics (the primacy of the social). From these two commitments arise the moral sense and the institutional architecture of the liberal state. So far as the first is concerned, the state is, on the liberal view, a "negative virtue" whose character and legitimacy resides in "what it prevents rather than what it engenders." accounts for the institutional forms so familiar and so intertwined in liberal states, limited government and social freedom. A limited state, a liberal state, is one that acknowledges its devolution from, and containment by, the social and it is, therefore, one for which the social serves as a moral-ethical power greater and higher than its own. Such a state erects barriers to its own power in order to honour the primacy of the social. But its governance does not necessarily end there. The liberal state may also act to preserve and to protect the personal sovereignty of those subject to its rule by supporting the life-forms through which that sovereignty is exercised and accomplished. In this fashion does it deliver its primary good, social freedom, which is but the positive freedom of a free people to construct their lives and affairs by means freely chosen by each of them.

The sphere of social freedom, which the state in this way exists to preserve, is known in liberal political and legal philosophy as civil society. ${ }^{78}$ But nothing turns on the name. What

I can here only sketch this relationship. For a more detailed account, see "Transformation." supra notc 9 and F.C. DeCoste. "What's the Charter Got to Do With II?" in Daniel Cere \& Douglas Farrow. cds.. Divorcing Marriage: Unveiling the Dangers in Canada's New Soctal Experment (Montreal \& Kingston: McGill-Queens University Press, 2004) 120.

$" \quad$ Stuart I lampshirc. Immocence and Experience (Cambridge. Mass : Harvard Universily Press. 1989) al 68.

77 There is a rich, and steadily growing, literature devoled to it. Sec e.g. Jean L. Cohen \& Andrew Aratto. Civil Society and Political Theon' (Cambridge. Mass.: MIT Press. 1992). John Fihrenbetg. (iwi Socier): The Critical Hisrory of An ldea (New York: New York University Press, 1999): Don l: I:herly. ed., The Essential Civil Society Reader (Lanham. Md.: Rowman \& Litlefield Pub., 2000). Simune Chambers \& Will Kymlicka, eds., Alternative Conceptions of (ivil Society (Princelon: Princelun University Press, 2002): and Nancy L. Rosenblum \& Rober C. Post. eds.. ('ivil Sinciet) and Government (Princeton: Princeton University Press, 2002) 
is important is the message, at once moral and institutional, that that name is meant to send: first, that there exists a life-world beyond law and politics for the sake of which the state exists and from which it draws its legitimacy; and, second, that the state acts for the sake of that life-world and, therefore, with authority, only when its actions neither diminish nor dominate the life-world. What a liberal state may not do, therefore, is manage the life-world by imposing values, whatever the reason and whatever their source, upon it. What a liberal state must do, if it does anything at all, is recognize and acknowledge, and in that fashion, honour and preserve, the life-world. ${ }^{79}$

That, in the Same-Sex Reference, the federal executive and the Court answered the statesociety question in a tone and grammar very different from this, should, I hope, be clear. Rather than parsing the argument of the second part of this comment, I wish instead to consider in finer detail the method the state here deployed to claim sovereignty over marriage. From that exploration, one may learn how neo-liberal states like ours seek to maintain legitimacy despite their transgression of fundamental precepts of liberal governance. One might also learn something of the consequences of their so doing.

What such states do, and what the Canadian state has done here, is to pretend that their perfectionist programmes and policies conform to, and sound in, the commandments of liberal governance. In the Same-Sex Reference, there are two such pretenses: first, that the state remains constrained by a higher moral-ethical power; and, second, that legal history secures the state's view that marriage exists in two forms, a political form (civil marriage) and a social form (religious marriage). The first is pretense because it identifies that higher power, not with the life-world beyond law and politics, but with the state's own perfectionist values as they reside in the state's own redemptive constitution. The second, on which 1 will dwell, is pretense because legal history, honestly and seriously considered, supports no such distinction between civil and religious marriage.

Let me make three things painfully clear: first, there can be no marriage in the required political sense, just because liberal states cannot claim ownership over social institutions (rather - and on the pain otherwise of the loss of their legitimacy - theirs is either to ignore or else to recognize and to preserve those institutions); second, the civil/religious marriage distinction is fiction, not, note, a legal fiction, but a political fiction, plain, pure and simple; and, third, the judicial branch has, over the last several years, spun that fiction whole-cloth through its wholesale misinterpretation and misrepresentation of legal and social history.

So far as the latter is concerned, the facts are these: (a) prior to the thirteenth century, when the Church finally managed to take control of it, marriage was an entirely social practice; (b) marriage only became a sacrament in 1439; and (c) the Catholic Church only began requiring the attendance of a priest for valid marriage in 1563 , after the Reformation. ${ }^{80}$

7" The caveat noted earlier - see supra note 55 - of course continues to apply here.

5. In 1563, the Council of Trent adopted the decree Tametsi, which, certain exceptions aside, invalidated marriages that did not take place in the presence of the parish priest of one of the couple and of at least two witnesses. The decree reversed what had been the Church's law since at least the twelfth century. that marriages entered into clandestinely, without ceremony and without the presence of a priest, were valid, even if unlawful. By the sixteenth century, virtually cvery European state had either adopted the decree Tametsi or promulgated secular legislation to the same effect, to invalidate clandestine marriage. 
The state came to marriage even later than did the Church. Indeed, it was not until 1753 , with the passage of Lord Hardwicke's Marriage Act, that the British state became a significant player in the joining together of men and women as husbands and wives. ${ }^{81}$ However, the manufacture of the distinction is not a consequence alone of a failure by our judges to acknowledge and address the history of the institution on which they had set their constitutional sights. Alas, they had also to manhandle, in fashion approaching deceit, the state's relationship to marriage, over the wealth of our tradition and since 1753 particularly.

The distinction between civil and religious marriage can serve as permission to make marriage pass (neo-)constitutional muster, only if civil marriage might somehow be construed as a positive act of the state. But this is no easy matter. None of the classics of our legal tradition - not Bracton, ${ }^{82}$ Fortescue ${ }^{83}$ Coke $^{84}$ or Blackstone ${ }^{85}$ - at all helps in construing marriage as a construction of the state: though each of them deals with marriage ${ }^{86}$ none of them defines marriage nor reports any court as having done so. Nor does legislative history assist. Until quite recently, ${ }^{87}$ the legislative branch found it unnecessary to define marriage; rather, whenever the state spoke of marriage, it apparently proceeded on the assumption that marriage had a social and legal meaning so plain that taxing it with definition was besides any point.

None of this, however, has served to impede our committed judiciary. On the bare basis of an 1866 House of Lords decision, it has, rather, sought to convince that civil marriage is

England remained the exception, until the promulgation in 1753 of Lord Hardwicke's Marriage Acr: sec infra note 81. See Lawrence Stone, The Family. Sex and Marriage in England 1500-1800, abr. ed. (New York: Harper and Row. 1979) at 30. See also llarold J. Berman. I.an and Revolurion: The Formation of the Western Legal Tradition (Cambridge. Mass.: Harvard University Press, 1983) at c 6 [Law and Revolution].

With this $A c r$. England finally joined Europe in invalidating clandestint marriage. The $A c /$ was replaced in 1873 with a statute that remains in force in England and that, in one fashion or another, is the law in every Anglo-American legal jurisdiction. The lesson of the $A c t$, and its continuing influence, for present purposes, is this: that the Act was intended, by in effect replicating Church law, to support marriage and not to proclaim state sovercignty over it. See R. B. Outhwaite. Clandestine Marriage in England. 1500-1850 (London: Hambledon Press, 1995) Rebecca Probert. "The Judicial Interpretation of Lord Hardwicke's Act 1753" (2002) 23:2 J. Leg. Hist. 129. Stone, ibud at 29-34; and John R. Gillis. For Befler. For Worse: British Marriages 1600 to the Present (New York: Oxford University P'ress. 1985) al esp. 17-31, 88-89. Supra note 71 .

Sir John Fortescue, On the Laws and Governance of England (circa / 170 ), ed. by Shelley L ockwood (New York: Cambridge University Press, 1997).

Sit Edward Coke, Institules of the Laws of England (1628, 1642. 164t) (London: W. Clarke \& Sons, 1817).

Sir William Blackstone, Commentaries on the Lan's of England, (1765-1769) (Chicago: University of Chicago Press, 1979).

Each, rather, deals with the rights and obligations attaching to the status of husband and wife and. in so doing. with the doetrines of unity and consortium that logether delined the nature and content of the marital relationship at common law.

The move to definition was a response to judicial occupation will sime-sex marriage. This response took sluape first in a Commons motion (see supra note 19) and subsequently in Bill C-23, An ACr to modernize the Statutes of Canada in relation to benefits and obligations, 2nd Sess.. 36th Parl., 2000. cl. 1.1 [now: Modernization of Benefits and Obligations Act. S.C. 2000, c. 12, s. 1.1] of which reads as follows: "For greater centainty, the amendments made by this Act do not affect the meaning of the word 'marriage," that is, the lawful union of one man and one woman to the exclusion of all others." 
indeed a state-created entity that might, unlike religious marriage, properly be made to dance to the state's constitutional tune. Hyde v. Hyde and Woodmanse $e^{88}$ concerned whether a party to a polygamous marriage contracted in a foreign jurisdiction (there Utah) was entitled to matrimonial relief or to a declaration as to the validity of the marriage in the English courts under the Divorce Act then governing those matters in England. ${ }^{89}$ The Court in Hyde answered negatively in both regards, and those answers remained the rule in Hyde until abolished by statute. En passant, ${ }^{90}$ the Court delivered itself of the following opinion on the nalure of marriage:

What, then, is the nature of this institution as understood in Christendom? Its incidents vary in different countries; but what are its essential elements and invariable features? If it be of common acceptance and existence, it must needs (however varied in different countries in its minor incidents) have some pervading identity and universal basis. 1 conceive that marriage, as understood in Christendom, may for this purpose be defined as the voluntary union for life of one man and one woman, to the exclusion of all athers. "I

According to our judges - including, apparently, those sitting in the Same-Sex Reference $e^{22}$ - these words prove that marriage, in its civil form, is a positive creation of the state. Of course, the definition in Hyde, on any responsible reading, proves no such thing. Just the contrary: what the Court was, by its own account, about in Hyde was not prescription, but recognition. That is, the Court was undertaking, not to legislate what constitutes marriage, but rather to determine what in societies such as ours is recognized as constituting the form of life, the "[i]nstitution," "93 we know as marriage. That the Court takes pains to distinguish the institution itself from "the variety of legal incidents" that "the laws ... throw about" the institution makes plain, I should think, that it was not conflating marriage as a cultural practice with the law of marriage, and, still less, claiming state sovereignty over marriage. ${ }^{94}$ So viewed, the rule in Hyde, if there be a rule at all, is that marriage is a form of life to which the state in certain measure responds, but which it does not itself create.

There is a distinction that is properly at play here, but that distinction does not reside in the faux distinction, concocted by the judicial branch, between civil and religious marriage. The distinction that counts is, rather, the distinction between state and society. The Supreme Court of Canada, of course, hides behind its investment in the civil-religious distinction, in order not once to acknowledge that this is so. Yet, by the same means, it does nonetheless provide an answer to the law and society question, at least so far as marriage is concerned. That answer is this: that, as regards this form of life, the political has primacy over the social. Nor is this answer modestly delivered: because marriage has no fixed political or legal meaning, it stands now entirely as the handmaiden of the state, at beck and call to the state's always revisable interests and values. Whether this commitment to the primordiality of political causation can be made, as the Court appears to think, without cost to the remainder

This analysis of Hyde is taken in large part from "Transformation," supra note 9 at 623. I say "in passing." because, since the matter at issue in /byde was polygamy and not helerosexuality, the detinition, on a strict reading. is obiter as regards the latter.

Hyde, supra note 39 at 133.

Same-Sex Reference, supra note 3 at paras. 21-22.

Hyde, supra note 39 at 133.

Ibid. 
of social life - and to family and religious life particularly - is the matter to which we must now turn. That this now becomes a necessary concern discloses, without more, the significance of the departure undertaken by the Supreme Court of Canada in the Same-Sex Reference.

\section{B. Faitu and Fanil.y: Pi.ace and Consequences}

Faith and family - the practices of transcendence and of the transmission of cultural attachments - stand at the very heart of autonomous social life and, because they do, they are together the primary elements of that moral-ethical order which alone can tame Leviathan and render it the modest and moderate enterprise that liberal political morality commands it to be. Before proceeding to the effects that the present claim of state supremacy over marriage might have on each of these, it will be prudent first to explore, however briefly, the contributions of faith and family to limited government.

\section{PIACF}

As noted earlier, ${ }^{95}$ in rejecting what it (incorrectly) took to be the common law legislation regarding marriage in Hyde, the Court took exception to the Hyde Court's reference to Christendom. As put by the Court: "The reference to 'Christendom' is telling. Hyde spoke to a society of shared social values where marriage and religion were thought to be inseparable. This is no longer the case. Canada is a pluralistic society. ${ }^{196}$ Now, this is of present interest, not because, assuming the Court meant to declare the Hyde Court sectarian, it is clearly wrong. ${ }^{97}$ The interest resides, rather, in the passage's display of a woeful historical illiteracy, and in its disclosure of a fundamental misapprehension of the place of religious life in the liberal project.

So far as the former is concerned, it is remarkable indeed that our highest Court appears entirely unaware of the importance, historically, of Judeo-Christian culture to the development of the Euro-American legal tradition. As space prevents my parsing the relevant literature, ${ }^{98}$ two comments will have to suffice. First, it is everywhere (else) accepted that "as a matter of historical fact the legal systems that are heirs to the Western legal tradition have been rooted in certain beliefs or postulates ... such as the structural integrity of law its

Same-Sex Reference, supra note 3 at para. 22.

Wrong on the following two counts: first, it is very likely. given the text of the entire judgment in $H y d d$. that the Court meant by Christendom simply to refer to states kindred to the U.K. because they, like it. are states in the Euro-American legal tradition; second, even were that not the case, the derogatory "sectarian" would be proper only were it applied with discipline and such discipline would preclude its use as regards the Court in Hydu. Regarding the latter, see e.g. Michacl J. Perry. love and Ponter: The Role of Religion and Norality in American Politics (New York: Oxford University Press. 1991) at 106 (defining sectarian argument as one that "relies on experiences or premises that have little if any authority beyond the confines of one's own motal or religious community").

Or which Harold Berman's groundbreaking work is the start and the center. See Law and Revolution. supra nute 80 and Harold J. Berman, Law and Revolution II. The Impact of the Protestam Reformations on the Western Legal Traditions (Cambridge, Mass.: The Belknap Press of' Harvard Universily Press. 2003). 
continuity, its religious roots, its transcendent qualities." ${ }^{\text {"99 }}$ Second, it is everywhere (else) understood that certain central commitments of that tradition - and here especially included are moral equality and constitutional governance ${ }^{100}$ - are unintelligible, both as historical accomplishments and as normative ends, without the sustenance of Euro-American religious culture.

Not only is religion central historically in these ways, the project of modest governance is impossible to conceive without the sorts of persons marked by the self-conception that religion makes possible. Human beings are transcendent needy beings every bit as much as they are resource dependent beings; $;{ }^{101}$ and the institutions of private religious life are a response to the former every bit as much as the institutions of private property are a response to the latter. Nor only that: modest government is no more possible in the absence of private religious life than it is possible in the absence of private property. This is so, in both regards, because modest governance, limited government, requires subjects who conceive of themselves as independent from the state and who seek their spiritual and material ends, not through and in the state, but by means of the institutions, the patrimony of private life, which exist beyond the state.

All of this holds, historically and normatively, for family as well. The Western ideal of the family arises, simultaneously, from the acknowledgement of, and from an attempt to overcome, the frailty of human knowledge and judgment and the ambiguous worth of human creations. Our faith in the family is, for these reasons, at root a rejection of the artifice and arrogance of politics. ${ }^{102}$ At the same time, however, the practices of family life have been thought crucial to proper politics because those practices alone are thought capable of forming persons seized of the character and disposition necessary for the flourishing of liberal political culture. ${ }^{103}$

Faith and family, then, are central to the project of liberal governance. They are the sites most subversive of the tendency of states to imperial expansion and despotic consolidation. They are this both because they are, by nature and stature, the practices most removed from the spirit of politics and because each is, for that very reason, a foundry in which persons of the sort required for limited government are alone to be formed. J. Law \& Religion 3 at 41.

(6) See e. g. Michael J. Perry, Under (iod? Religious Faith and Liberal Democracy (New York: Cambridge University Press, 2003); Christopher L. Eisgruber \& Lawrence Sager, "Religious Libenty and the Moral Structure of Constitutional Rights" (2000) 6:3 Legal Theory 253; J.P. Day. "Collective Liberty and Religious Liberty" (1986) 23 American Philosophical Q. 243: and especially, Emmanuel Levinas. "Reflections on the Philosophy of Hitlerism" (1990) 17 Critical Inquiry 62 (trans. by Sean Hand). In the cause of abundant caution, I should add that these claims are made with Hartian modesty in the sense that they arise from "[r]eflection on some very obvious generalizations - indeed truisms concerning human nature and the world in which men live ... as long as these hold good." See H.L.A. Hart, The Concepr of Law (Oxford: Clarendon Press, 1961) at 188.

I": See e.g. Philip T. Neisser, "The Will to Harmony and the Pursuit of Family" (1994) 20:3 Social Theory \& Practice 253.

I'1 See e.g. Jennifer Roback Morse, "No Families, No Freedom: Iluman Flourishing in a Free Society" (1999) 16:I Social Philosophy \& Policy 290. 


\section{CONSEQUENCES}

The single most important condition of human freedom is the diffusion of power in a society. In societies served by liberal states, power is diffused in two fashions. So far as the state itself is concerned, it is constructed in a fashion so that power is spread between its own branches. So far as society is concerned, the life-world is preserved as the realm of freedom by disenabling politics there and by according special, and indeed sacred, sovereignty to the practices of faith and family. I want to suggest that the Canadian state's same-sex marriage initiative changes these, the structures of public and private life of free societies.

Committed states - those that believe in a socio-political ideal rather than in alwaystransient policy ideals ${ }^{104}$ - are ideological states, and ideological states are morally unified and structurally consolidated states. I have already characterized the Canadian state as a state unified under the banner of an expansionary, social constitution. ${ }^{105}$ Brief attention must now be paid to how a state of that sort degrades and erodes the separation of powers.

Montesquieu claimed that "[p]olitical liberty ... is present only when power is not abused," and that for power not to be abused, "power must check power by the arrangement of things." 106 "In order," he thought, "to form a moderate government, one must combine powers, regulate them, temper them, make them act; one must give one power a ballast, so to speak, to put it in a position to resist the other." 107 Thus was he led to distinguish between the legislative, executive and judicial powers and to propose that "liberty is formed by a certain distribution of the three powers." 108 "When legislative power is united with executive power in a single person or in a single body of the magistracy, there is no liberty... Nor is there liberty if the power of judging is not separate from legislative power and from executive power." 109 This must be so, he thought, because power will inevitably be abused, unless one power is "chained to the other by their reciprocal faculty of vetoing" 110 or unless they are "counter-balanced." "11

According, then, to the classic agonistic view of the separation of powers, the proper relationship between the powers of a state devoted to, and fit for, liberty is one of struggle and resistance. Each of the powers, that is, should be a centre of resistance, one against the other, to the proclivity of the state as a whole to serve its own good rather than the good of the liberty of its subjects. The Canadian state, as delivered in the Same-Sex Reference, is no such state. That state, rather, speaks with a unified constitutional voice, in service to its settlement of constitutional values, and by means of its assessment of "the realities of modern

I take the ideal/ideals distinction from Fishkin. See James S. Fishkin. Justice, Equal Opportunity: and the Family (New Haven: Yale University Press, 1983) (arguing for a "limited liberalism." which offers conflicting principles without any single vision of the just society).

Supra Part II.D. 
life." 12 The branches of this state are, each of them separately and all of them together, bound to the task of "structuring the exercise of [their] power"1'3 so as to promote the state's values and, in that way, to enrich society. "I4 Such a state, of course, makes jest of the separation of powers and of the liberty that state structure aims to honour and preserve.

The structure of the life-world, faith and family especially, fares no better than does the structure of the public realm under the new day of state governance fully announced and finally accomplished in the Same-Sex Reference. My argument in this regard, I should note, is not based on the Court's uncertainty as regards the ambit of religious liberty, as threatening to some as that might (properly) 1 appear. ${ }^{116}$ Nor does it arise from the Court's insouciant carriage of objections arising from the maintenance of the traditions of marriage and family life ${ }^{117}$ or concerning the effects same-sex marriage may have on marriage. ${ }^{118} \mathrm{My}$ argument, rather, concerns the socio-legal position in which faith and family are now placed.

Two matters provide entry. When it was argued that "the Proposed Act will have the effect of imposing a dominant social ethos," 19 the Court would have none of it and summarily dismissed the concern. ${ }^{120}$ Yet, the Court also announced as a value of our constitutional jurisprudence that the Charter never be "trivialize[d]." 21 It is in the confluence of these two - the dismissal of concerns over the impact of state on social life, on the one hand, and the cloying solicitude about the status of state values, on the other - that my argument emerges. Simply put, the argument is this: that the Court has elevated politics over social life so as, first, to demand the conversion of the practitioners of faith and marriage to state values and, second, to weaken their fidelity to the life-world.

The elevation arises from the Court's very perspective. For it, social life exists to be located, enclosed and judged by the state's constitutional values. The practices of social life are, on this view, epiphenomenonal: rather than being seen as prior and superior to state, they are instead reduced to something upon which the state gazes as rights and upon which it may act as of right in service to constitutional equality. So rendered, it is easy, as for this Court,

Same-Sex Reforcence, supra nole 3 at pata. 22.

lbid. at para. 23

Ibid. at para. 46.

This perception is proper for a variety of reasons, one of which is especially prominent. namely, that Western states have acted as regards to religion so as to contain and to diminish religious freedom. See e.g. Julien Taieb, "Freedom of Religion: from France to the United States, a National Conflict of Law" (2004) 4:3 Global Jurist Advances 1; and Richard W. Garnett, "Assimilation. Toleration, and the State's Interest in the Development of Religious Doctrine" (2004) 51 UCLA 1. Rev. 1645.

Same-Sex Reference, supra note 3 at paras. 58 (frecdom of religion subject to "exceptional circunistances which we cannot at present foresec") and 60 (subjecl to "unique circumstances with respect to which we will not speculate").

lbid. at paras. $\mathbf{2 4 - 2 8}$.

lbid. at paras. $45-46$.

lbid. at para. 47.

Ibid. at para. 48.

Ibid. at para 51 . 
to proceed on the understanding, first, that the state, properly, has a view of social life and, second, that social life has no view of the state, ${ }^{122}$ not least any that ought to be heard. ${ }^{123}$

This message - state declared and constitutionally enforced - asks much of its recipients. Minimally, it demands that the state's subjects, as persons, acknowledge the final and binding authority of the state over the life-world. To the extent that it succeeds in that demand, it will also effect a conversion among its subjects from the values of private life to public values, at least to the extent that the former, in the state's assessment, conflict with the latter. This, in turn, works the moral weakness mentioned. Fidelity to one's world becomes contingent because fidelity is always subject to state supervision and denunciation.

As the unified state makes jest of limited government, the elevation of the state over social life in these ways makes jest of social freedom. For the test of social freedom is its defense of freedom from and against the claims of law: it does not exist where its dominion is whatever remains, for the time being, beyond the law's empire. Freedom is not concocted from, nor can it be preserved as, crumbs of tolerance from Cacsar's table.

\section{THE COURT'S CAVEAT}

As noted previously, the Court declined to answer the question, added by the Martin government, concerning the constitutional acceptability of the opposite-sex definition of marriage. My concern here is not the arguments that the Court offers in support of its decision to decline (which, in my view, are, each and all, bootstrapping of a very unhappy sort). My object rather is to examine the difference, if any, its decision on this matter makes to what I am claiming is the overall structure and import of its opinion.

The Court's decision has been widely hailed as an exhibition of judicial wisdom and statecraft. ${ }^{124}$ I think these views are profoundly mistaken. Rather than statecraft and, even less, an acknowledgement of Parliamentary authority, the Court's decision to decline to answer to this matter signals its determination to elide delivering the message that its own jurisprudence and the conduct of the lower courts in same-sex marriage cases required of it. On the one hand, it sought, as we have seen with much certainty and conviction, to preserve the judgment of the lower courts as regards the constitutional propricty of same-sex marriage. On the other hand, by declining here, it sought to distance itself from the premise on which those courts made their constitutional determinations; namely, that the opposite-sex definition of marriage is constitutionally diseased because incurably discriminatory. Thus does the Supreme Court of Canada deliver instead the constitutional alchemy here on display: samesex marriage is a constitutional commandment, but that commandment does not require the denunciation of the opposite-sex definition. Of course, as the lower courts rightly

122 For just such a view - there of the state from the perspective of faith - sec David Fergusson, Church. State and Civil Socieb' (New York: Cambridge University Press, 2004)

13) Foreign Aflairs Minister Pettigrew recently rendered this with crude and cruel candour: see Elizabeth Thompson \& Anne Dawson, "Church told to butt out: same-scx debate no place for religion: Pettigrew" National Post (28 January 2005) AI.

12. See e.g. “Calling Parliament's Bluff," Fditorial, National Post (10 December 2004) A23; Andrew Coyne, "True to the Charter" National Post (1I December 2004) A24: and "How Deferential is the Supreme Court?," Editorial, Globe \& Mail (24 January, 2005) ^12. 
acknowledged, it does. Sloughing that necessity off to Parliament or worse still to the now diminished communities of faith, to await another day, is the very opposite of candour, wisdom and statecraft. It is rather sleight of hand and prudence of a self-directed and selfserving sort.

\section{CoNCL.usion}

A decent society is one in which institutions do not humiliate. ${ }^{125}$ A decent state is one whose institutions do not humiliate their subjects as persons. The Canadian state, in my view, is fast becoming an indecent state in just that sense, and I shall conclude this already too long comment with a brief exploration of the causes and consequences of that most unhappy political circumstance.

The immediate cause is, of course, constitutional paternalism. The Canadian state unprepared as it was, by dint of its parliamentary nature and history, to handle the republicanism abruptly introduced into it by the Charter in 1982 - has seen its Constitution become, in very short order, not only a means for the expansion of state power over private life, but also the end towards which both the state and society are properly to strive. Need I say, neither this de facto expansion nor this normative elevation was undertaken for the purpose of, or by way of, an assault on the institutions, traditions and practices of civil society. Just the contrary: as paternalism is wont to do, the motive has been benevolence and the means the gradual pollution and, with that, the inexorable assimilation, of one set of values by another. Yet, paternalism is not, for either reason, saved of the sin of humiliation. This is especially so when the values causing the pollution and assimilation are state articulated and sanctioned. For in that case, the lowering of self-respect and self-reliance of persons in their lives and affairs is not a matter of persuasion, but of coercion.

This novel historical and constitutional narrative of course carries many costs, but two in my view are especially important. The first of these is the sapping away of political conscience. For those seized of high-minded constitutional conviction - and this is everywhere on display in the course of the state's carriage of the same-sex marriage matter - nothing remains of a political conscience that restrains because it acknowledges that some things are impossible and that some aspirations cannot be satisfied. ${ }^{126}$ Let loose from tradition and traditional moral viewpoints, political conscience instead becomes permission and, as here, actions and policies inconceivable and incomprehensible barely a generation ago become not just imaginable, but, depending on whichever ideology has replaced tradition, necessary.

The second cost is a cost to qualities and experience of social life. The imperialism of the neo-constitution blurs borders, makes porous barriers and renders possible the impossible. In so doing, it scrapes away the bumpy, chaotic surfaces of life lived in freedom beyond the

I3s For a splendid book-length exploration of this precept of civilized life, sec Avishai Margalit, The Decent Society (Cambridge. Mass.: Harvard University Press, 1996).

12. Hampshire (supra note 77 at 72) captures this perfectly: "When justice needs to be enforced and is enforced, the scene is not one of harmony; some ambitions are frustrated. $A$ barrier is erected, an impossibility declared." 
state. In its place, the state constructs a life ordered by decree, a life no longer fragmented by difference but flattened by the iron of coercive norms. ${ }^{127}$

Canada, of course, is alone in none of this. Due perhaps to its political circumstances, past and present, it has however distinguished itself, as it has once again in the Same-Sex Reference, as an exceptionally devoted, if not as a very adept, neo-liberal state.

\section{POSTSCRIPT}

We're talking about changing one of the central and longstanding institutions of society.

$$
\text { - Federal Department of Justice (1 February 2005) } \text { (28 }^{128}
$$

As he tabled the landmark Civil Marriage Act ..., he talked with messianic zeal about the "march towards equality in this country" and "proceeding with a transformative constitutional process."

$$
\text { - John Ivison }{ }^{129}
$$

On I February 2005, the federal executive tabled in the House of Commons its legislative response to the Supreme Court of Canada's advice in the Same-Sex Reference. It tabled the Civil Marriage ACt - Bill C- $38^{130}$ — it says, in order "to extend legal capacity to marry for civil purposes to same-sex couples while respecting religious freedom." 131 And it had to do this, it declares, because it "has responsibility to support [the] institution [of marriage]" because "that institution ... strengthens commitment in relationships and represents the foundation of family life for many Canadians." ${ }^{132}$ What it is in fact doing, of course, is continuing (with renewed vigour and expanded boldness, yes, but continuing nonetheless) the task of spreading the good news of the constitutional values of which it sees itself as

127 For an exploration of the effects of equality jurisprudence along these lines, see Deborah $\mathrm{L}$. Brake, "When Equality Leaves Everyone Worse Off: The Problem of Leveling Down in Equality Law" (2004) 46 Wm. \& Mary L. Rev. 513.

12* See Department of Justice Canada, "Frequently Asked Questions - Civil Marriage Act" (I February 2005), online: Government of Canada <http://canada.justice.gc.ca/cn/ncws/nr/2005/doc 31378.html>.

(2.) John Ivison, "Rights crusade continues apace" Notional Post (2 February 2005) A1. This has been the only report on the Minister's comments on tabling the Bill that I have been able to uncover. Neither the Department of Justice's Web site. nor the Web site of the Parliament of Canada, so far offers the text.

13. After a lengthy, ten-pan preamble, and excluding a short title provision (s. 1). the Bill consists of fourteen sections, the first three of which concern the re-definition of marriage and the remainder of which concern what the Bill terms (as it turns out modestly) "consequential amendments" to a number of other statutes. The re-definition sections read as follows:

2. Marriage, for civil purposes, is the lawful union of two persons to the exclusion of all others.

3. It is recognized that officials of religious groups are free to refuse to perform marriages that are not in accordance with their religious belicfs.

4. For greater certainty, a marriage is not void or voidable by reason only that the spouses are of the same sex.

Bill C-38, An Act respecting ceriain aspects of legal capocity for marriage for civil purposes, I st Suss., 38th Parl, 2005, cls. 2-4.

i1 Department of Justice Canada, "Background - Civil Marriage Act" (I February 2005). onlint Government of Canada <http://canada.justice.gc.ca/en/news/nr/2005/doc_31376.html> 
master and commander. Its methodology is what one would expect. Social life will be further occupied by the state; and, through the state's coercive poiver, social relationships will be, not just re-defined at law, but changed root and branch by law. I wish by way of final comment briefly to disclose how this task is undertaken in this Bill as regards the family and at what cost.

The majority of the "consequential amendments" contained in sections 5 through 15 of the Bill aim, in the statutes at which the sections are directed, to replace the term "natural parent" with the term "legal parent"133 and the term "blood relationship" with the term "any legal parent-child relationship." ${ }^{34}$ Their aim, that is, is to de-naturalize the family by rendering familial relationships, in their entirety, expressions of law. But relationships of that sort bled as they are of the stuff of social tradition and experience - are no longer family relationships at all. They are rather policy relationships, defined and imposed by the state.

Ways of life disintegrate for any number of reasons. But two phenomena, in my view, always attend their decline - alienation and forgetfulness. When practitioners of a way of life become detached from their labours, they become only partially engaged in, and tend no longer to experience themselves as fully revealed through that way of life. Forgetfulness is no less a corrosive force. When practitioners of a way of life lose a sense of historical depth and connection, their sense of the present, as a moment in moral time, tends to fail as well. Tradition militates against both of these forces. It bestows on practitioners a sense of being located in a continuing way of being, one that existed before they came to it and one that will continue after they depart it; and it arms them with a reason transcendent to themselves and, with that, with the will, to resist the forces that, in modern life especially, would lure them into detachment and forgetfulness.

It occurs to me that the initiatives being carried forward in this Bill are an assault on the traditions of family life and that they risk the disintegration of that way of life, at least to the extent that they lure fathers and mothers, and husbands and wives, into detachment from and forgetfulness about the moral point of family life. (Sth Supp.), as amended. Supra note 130, cl. 10-12.

i1. Ibid., cl. S. Section 5 of the Bill makes work this replacement in the Canada Business Corporations Act, R.S.C. 1985, c. C-44, as amended, and s. 6 does the same as regards the Canada Cooperatives Act, S.C. 1998, c. I, as amended. 